\title{
IMPROVING STUDENT ACHIEVEMENT WITH SMART SHEETS MEDIA IN ISLAMIC CULTURAL HISTORY LESSON AT THE ELEVENT GRADE STUDENTS OF MTSN TARUSAN
}

\author{
SASMINI
}

Volume 1 Nomor 1

JIPS ISSN: 2579-5449

\begin{abstract}
To be able to learn something well, we need to hear, see, ask questions about it, and discuss it with others. Not only that, teachers need to "do", which describe something in their own way, showing for example, tried to practice skills and tasks that require $\mathrm{p}$ What Knowledge they have earned.

Problems to be studied in this research are: a) How improve learning outcomes Islamic cultural history through smart method in class XI sheets MTsN Tarusan in July 2016? b) The steps made in improving the learning outcomes of students of Islamic cultural history?

This research is a Class Action Research (PTK), as for the steps to be performed in this PTK model developed by Kurt Lewin as mentioned in Dikdasmen (2003: 18) that the stages or so-called cycle (round) consists of four

components which cover : (A) planning, (b) action / acting, (c) observation, (d) reflection.

Based on The results of learning activities that have been conducted during the study, and based on all the discussion and analysis that has been done can be summed up as follows: Learning with smart method sheets in Islamic cultural history lesson positively in improving student achievement that is marked by a mastery learning students in learning, namely (97.29\%). Application of the method school library media on learning history of Islam have a positive effect, which can increase students' motivation is indicated by an average of 80 and from interviews stating that students are interested and interested deng a $n$ cooperative methods Learning the history of Islamic culture so that they become motivated to learn.
\end{abstract}

Key Words: skill, practice, method 


\title{
PENINGKATAN HASIL BELAJAR SISWA KELAS XI MTSN TARUSAN DENGAN MEDIA SMART SHEETS DALAM PEMBELAJARAN SEJARAH KEBUDAYAAN ISLAM
}

\begin{abstract}
ABSTRAK
Untuk bisa mempelajari sesuatu dengan baik, kita perlu mendengar, melihat, mengajukan pertanyaan tentangnya, dan membahasnya dengan orang lain. Bukan cuma itu, guru perlu "mengerjakannya", yakni menggambarkan sesuatu dengan cara mereka sendiri, menunjukkan contohnya, mencoba mempraktekkan keterampilan dan mengerjakan tugas yang menuntut pengetahuan yang telah mereka dapatkan.

Permasalahan yang ingin dikaji dalam penelitian ini adalah:

a. Bagaimanakah meningkatkan hasil belajar sejarah kebudayaan islam melalui metode smart sheets pada kelas XI MTsN Tarusan pada bulan Juli 2016 ?

b. Langkah-langkah yang dilakukan dalam meningkatkan hasil belajar sejarah kebudayaan islam siswa?

Penelitian ini merupakan Penelitian Tindakan Kelas (PTK), adapun tahapan yang akan dilakukan dalam PTK ini menggunakan model yang dikembangkan oleh Kurt Lewin

bahwa tahap-tahap tersebut atau biasa disebut siklus (putaran) terdiri dari empat komponen yang meliputi : (a) perencanaan (planning), (b) aksi/tindakan (acting), (c) observasi (observing), (d) refleksi (reflecting).

Berdasarkan hasil kegiatan pembelajaran yang telah dilakukan selama penelitian, dan berdasarkan seluruh pembahasan serta analisis yang telah dilakukan dapat disimpulkan sebagai berikut: Pembelajaran dengan metode smart sheets dalam pelajaran sejarah kebudayaan islam positif dalam meningkatkan prestasi belajar siswa yang ditandai dengan ketuntasan belajar siswa dalam pembelajaran yaitu $(97,29 \%)$. Penerapan metode media perpustakaan sekolah pada pembelajaran sejarah kebudayaan islam mempunyai pengaruh positif, yaitu dapat meningkatkan motivasi belajar siswa yang ditunjukan dengan rata-rata 80 dan dari hasil wawancara yang menyatakan bahwa siswa tertarik dan berminat dengan metode kooperatif pembelajaran sejarah kebudayaan islam sehingga mereka menjadi termotivasi untuk belajar.
\end{abstract} seperti disebutkan dalam Dikdasmen (2003:18)

Kata Kunci: keahlian, latihan, metode

\section{PENDAHULUAN}


Latar Belakang, pembangunan di bidang pendidikan yang dilakukan oleh bangsa Indonesia dengan tujuan untuk meningkatkan kualitas SDM dan mencerdaskan kehidupan bangsa nampaknya perlu mendapatkan perhatian yang lebih serius, baik oleh pemerintah, pengelola pendidikan, maupun masyarakat.

Berkenaan dengan hal tersebut, sudah seharusnya peningkatan kualitas pendidikan dilaksanakan dalam semua jenjang pendidikan, termasuk di dalamnya pendidikan di MTsN. Untuk meningkatkan kualitas siswa, proses pembelajaran akuntansi termasuk satu unsur yang memerlukan penanganan dengan baik.

Berdasarkan informasi guru matematika kelas XI MTsN Tarusan pada bulan Juli 2016, nilai ulangan harian siswa kelas tersebut pada materi soal sejarah kebudayaan islam belum seperti yang diharapkan, dimana ketuntasan kelas yang dicapai sebesar 63,89\%.

Kenyataan ini menunjukkan masih rendahnya tingkat pemahaman siswa terhadap materi tersebut. Oleh karena itu, diperlukan upaya lebih lanjut dalam mengoptimalkan pembelajaran yang ada sehingga dapat meningkatkan hasil belajar siswa.

Materi soal dalam sejarah kebudayaan islam merupakan materi yang tergolong banyak sehingga akan menyita banyak waktu apabila guru tidak tepat dalam memilih media pembelajaran yang akan digunakan. Dalam hal ini, guru siswa kelas XI MTsN memilih menggunakan media buku paket dalam proses pembelajaran.

Berkenaan dengan hal tersebut, peneliti merasa bahwa penggunaan media buku paket dalam penyampaian materi soal sejarah kebudayaan islam sangat kurang efektif dan efisien. Hal ini dikarenakan penyampaian materi dalam media buku paket terkesan bertele-tele sehingga dikhawatirkan siswa akan kesulitan dalam menemukan dan memahami hal-hal penting dalam materi tersebut.

Untuk itu, meteri lebih tepat disajikan dengan menggunakan media Smart Sheets karena dengan media ini materi disampaikan secara runtut, sistematis dan memuat ringkasan hal-hal penting berkenaan dengan materi sejarah kebudayaan islam.
Berdasarkan uraian di atas, maka peneliti tertarik untuk melakukan penelitian tindakan kelas dengan judul "Peningkatan Hasil Belajar Siswa Kelas XI MTsN Tarusan dengan Media Smart Sheets dalam Pembelajaran Sejarah Kebudayaan Islam"

Berdasarkan observasi yang telah dilaksanakan, peneliti menemukan adanya beberapa masalah yang terjadi dalam proses pembelajaran sejarah kebudayaan islam, diantaranya adalah sebagai berikut : 1) Aktivitas Belajar didalam kelas masih kurang, dilihat dari hanya sekitar 2-3 siswa yang aktif menjawab pertanyaan maupun yang menyanggah jawaban yang diberikan oleh guru. 2) Selain itu, metode pembelajaran yang diterapkan oleh guru adalah metode ceramah, jadi membuat suasana kelas jadi tenang namun menyebabkan aktivitas siswa sendiri menjadi kurang, disamping itu kebanyakan siswa malas untuk mendengarkan penjelasan yang diberikan oleh guru karena menurut mereka metode ceramah yang diterapkan guru ini membuat suasana kelas sepi dan menyebabkan ngantuk para siswa. Kemampuan dalam mengerjakan soal kurang, dilihat dari tidak adanya siswa yang mau maju apabila diminta oleh guru untuk mengerjakan soal dipapan tulis, disamping itu soal yang diberikan saat pelajaran mudah untuk dikerjakan tetapi saat diadakan ulangan soal yang diberikan benar-benar susah, kurangnya latihan mengerjakan soal juga menjadi permasalahan yang dihadapi siswa dalam pembelajaran sejarah kebudayaan islam.

Dari kedua permasalahan diatas aktivitas belajar yang masih rendah dan kemampuan untuk menyelesaikan soal yang masih sangat kurang sehingga menyebabkan hasil belajar siswa pun tergolong rendah.

Berdasarkan latar belakang yang telah diuraikan di atas, masalah dalam penelitian ini dirumuskan sebagai berikut. 1) Apakah penggunaan media Smart Sheets dapat meningkatkan hasil belajar siswa kelas XI MTsN Tarusan dalam pembelajaran $\mathrm{se}^{\text {: } \sim \text { m h }}$ kebudayaan islam ? 2) Bagaimana penggı 156 media Smart Sheets sehingga meningkatkan hasil belajar siswa kelas XI M'I'sN 
Tarusan dalam pembelajaran sejarah Kebudayaan islam?

Pemecahan

Masalah, Peneliti menggunakan media smart sheets untuk meningkatkan hasil belajar Siswa Kelas XI MTsN Tarusan dalam pembelajaran sejarah kebudayaan islam.

Tujuan umum penelitian ini adalah : a Menggunakan media Smart Sheets untuk meningkatkan hasil belajar siswa kelas XI MTsN Tarusan dalam pembelajaran sejarah kebudayaan islam. b Mengetahui penggunaan media Smart Sheets sehingga dapat meningkatkan hasil belajar siswa kelas XI MTsN Tarusan dalam pembelajaran sejarah kebudayaan islam.

Tujuan Khusus , a Menggunakan media Smart Sheets untuk meningkatkan rerata hasil belajar siswa kelas XI MTsN Tarusan dalam pembelajaran sejarah kebudayaan islam hingga mencapai 75. b Menggunakan media Smart Sheets untuk meningkatkan ketuntasan hasil belajar siswa kelas XI MTsN Tarusan dalam pembelajaran sejarah kebudayaan islam hingga mencapai $80 \%$.

\section{PROSEDUR PENELITIAN}

Penelitian Tindakan Kelas (PTK) ini dimaksudkan untuk meningkatkan hasil belajar siswa yang berkaitan dengan proses pembelajaran di kelas, dengan menggunakan media pembelajaran smart sheets. Langkahlangkah yang ditempuh mulai dari perencanaan sampai dengan pelaksanaan penelitian akan dijabarkan dalam uraian berikut ini.

Penelitian tindakan kelas ini akan dilaksanakan pada tahun 2016 mulai dari bulan Juli sampai Agustus 2016 sebanyak 4 kali pertemuan yang dibagi menjadi 2 siklus. Siklus I sebanyak 2 kali pertemuan dan siklus II sebanyak 2 kali pertemuan. Subjek yang diteliti adalah siswa kelas XI MTsN Tarusan.
Penelitian ini merupakan Penelitian Tindakan Kelas (PTK), adapun tahapan yang akan dilakukan dalam PTK ini menggunakan model yang dikembangkan oleh Kurt Lewin seperti disebutkan dalam Dikdasmen (2003:18) bahwa tahap-tahap tersebut atau biasa disebut siklus (putaran) terdiri dari empat komponen yang meliputi : (a) perencanaan (planning), (b) aksi/tindakan (acting), (c) observasi (observing), (d) refleksi (reflecting).

Prosedur penelitian tindakan kelas ini secara garis besar dapat dilihat dalam tabel berikut ini :

\section{Tabel 1 : Siklus Kegiatan Penelitian}

- Merencanakan pembelajaran yang akan diterapkan dilaksanakan.

- Menentukan pokok bahasan

Perencanaan

Siklus I

Tindakan
- Mengembangkan rencana pelaksanaan pembelajaran (RPP).

- Menyiapkan media pembelajaran smart sheets

- Mengembangkan format evaluasi

- Melaksanakan KBM yang mengacu pada rencana pelaksanaan pembelajaran yang telah disiapkan menggunakan media smart sheets

- Melakukan evaluasi dalam bentuk tes kemampuan pemahaman konsep yang dipelajari. 


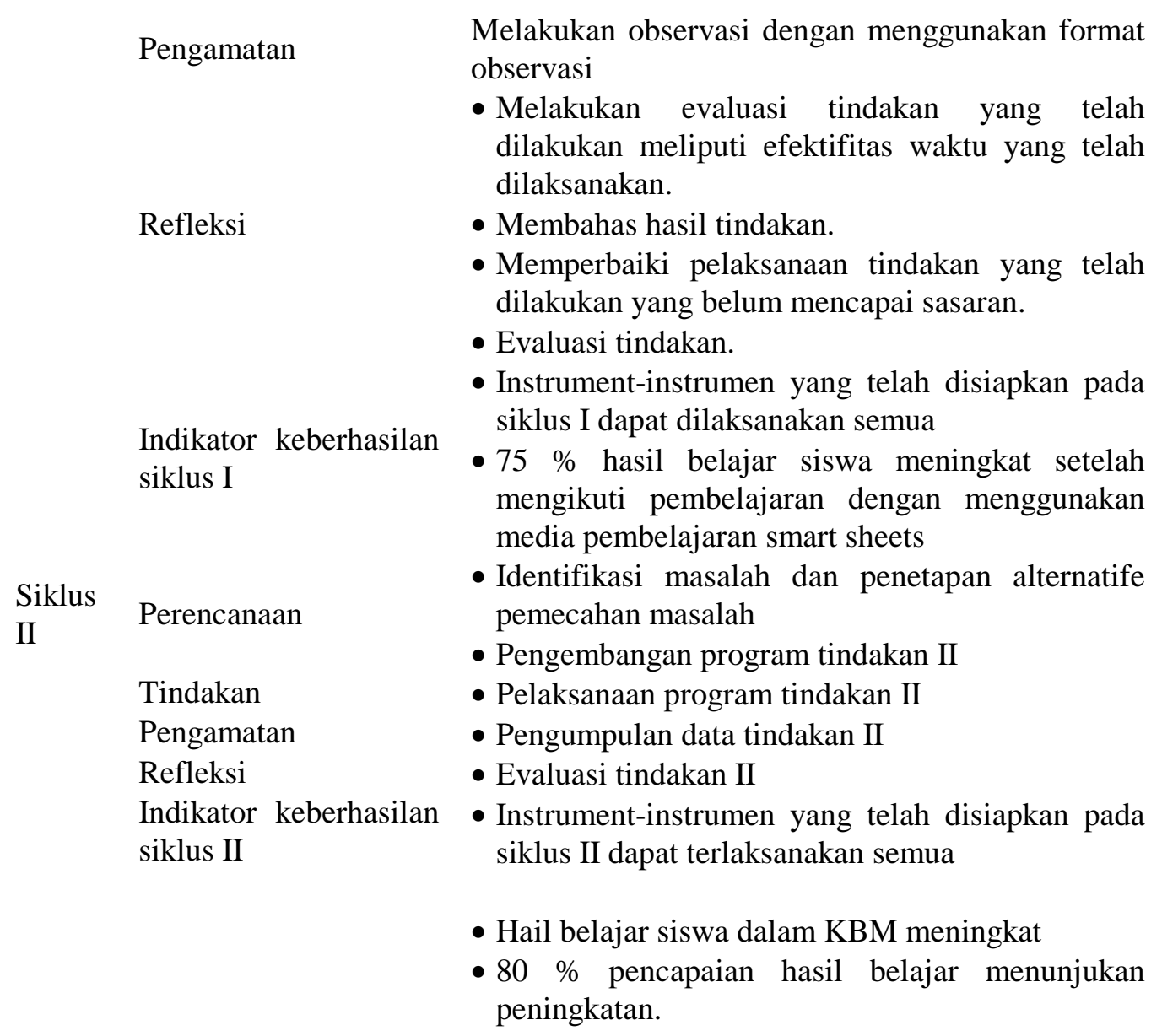

Sumber data penelitian ini adalah siswa, sedangkan jenis data yang didapatkan dalam penelitian ini adalah data kuantitatif dan data kualitatif yang meliputi : data hasil pretes dan postes hasil observasi terhadap proses Kegiatan Belajar-Mengajar, jawaban angket, jurnal harian/catatan lapangan, foto kegiatan

Pengumpulan data dilakukan melalui pretes dan postes, observasi, angket pada tiap siklus dan dilengkapi jurnal harian (catatan harian) serta foto (dokumentasi).

Data tes hasil belajar berupa data kuantitatif yang di peroleh melalui pretes sebelum diadakan tindakan pada masing-masing siklus dan postes setelah berakhirnya setiap siklus. Hal ini dimaksudkan agar setiap berakhirnya disetiap siklus dapat diketahui kemajuan dan perkembangan yang didapat oleh siswa melalui pembelajaran pemahaman materi pembelajaran dengan media pembelajaran smart sheets. Data hasil tes tersebut bisa di jadikan acuan, pertimbangan, bahan refleksi, untuk merencanakan pelaksanaan pada siklus berikutnya.

Observasi dilakukan untuk mengamati aktivitas siswa selama kegiatan pembelajaran berlangsung, dari observasi tersebut dapat dilihat peningkatan aktivitas belajar yang meliputi frekuensi aktivitas dan peningkatan kerjasama antar siswa dalam pelaksanaan pembelajaran.

Angket digunakan untuk melihat motivasi siswa dari pembelajaran yang telah dilakukan, dimana angket adalah merupakan tanggapan dari seluruh siswa terhadap kegiatan pembelajaran yang dilaksanakan, bermanfaat atau dapat dirasakan oleh siswa dalam rangka meningkatkan hasil belajar.

Seluruh kegiatan dalam proses pembelajaran tidak semuanya tercantum ( 158 lembar observasi. Oleh karena itu di len lagi dengan jurnal harian / catatan harian yaug 
merupakan alat bantu perekam yang paling sederhana yang memuat perilaku khusus siswa maupun permasalahan yang dapat di jadikan pertimbangan bagi pelaksanaan langkahlangkah berikutnya.
Untuk merekam peristiwa penting seperti aspek kegiatan kelas, aktivitas kelas atau untuk memperjelas data dan hasil observasi dari penelitian ini, di gunakan foto. Foto ini juga dapat membantu dalam evaluasi tentang datadata lainnya.

Teknik analisis data yang dilakukan dalam penelitian ini adalah sebagai berikut :

Data obsevasi ini di ambil melalui pengamatan yang dilakukan oleh kolaborator sebagai observer, yang dilakukan pada saat berlangsungnya kegiatan pembelajaran di kelas. Pengolahannya dengan menggunakan rumus :

\section{$\frac{A}{B} \times 100 \%$}

Dimana $\mathrm{A}=$ Jumlah siswa yang melakukan kegiatan

$\mathrm{B}=$ Jumlah siswa keseluruhan

Data Angket Menganalisis data hasil angket dengan menggunakan rumus sebagai berikut.

$$
\frac{\text { jumlah responden aktual }}{\text { jumlah seluruh responden }} \times 100 \%
$$

Data Tes Hasil Belajar

Peneliti menentukan nilai setiap siswa dari hasil pretes dan postes masing-masing siklus dengan pemberian nilai skala 100, dimana KKM (Kriteria Ketuntasan Minimal) untuk pelajaran Kimia adalah 70 . Kemudian menentukan banyaknya siswa yang mendapat nilai diatas atau sama dengan 70 (siswa yang sudah tuntas). Banyaknya siswa yang mendapat nilai $\geq 70$ di hitung prosentasenya dengan menggunakan rumus :

$$
\frac{j u m l a h \text { siswa yang tuntas }}{\text { jumlah seluruh siswa }} \times 100 \%
$$

Sementara skor nilai rata-rata diperoleh dengan cara menjumlahkan skor nilai seluruh siswa dibagi dengan jumlah siswa. Data Jurnal Harian

Peneliti sebagai orang yang terlibat secara aktif dalam pelaksanaan tindakan, dan juga guru lain sebagai observer menyimpulkan dan mendeskripsikan kejadian selama penelitian berlangsung baik pada siklus I maupun siklus II.

\section{HASIL PENELITIAN DAN PEMBAHASAN}

Data penelitian yang diperoleh berupa hasil uji coba item butir soal, data observasi berupa pengamatan pengelolaan belajar dengan penerapan metode pembelajaran interaktif dan pengamatan aktivitas siswa dan guru pada akhir pembelajaran, dan data tes formatif siswa pada setiap siklus.
Data hasil uji coba item butir soal digunakan untuk mendapatkan tes yang betulbetul mewakili apa yang diinginkan. Data ini selanjutnya dianalisis tingkat valir reliabilitas, taraf kesukaran, dan daya pembe 159

Data tes formatif untuk menge peningkatan prestasi belajar siswa setelah diterapkan belajar dengan penerapan metode 
pembelajaran dengan menggunakan pendekatan pembelajaran metode smart sheets dalam peningkatan kualitas pembelajaran mata pelajaran sejarah kebudayaan islam kelas XI MTsN Tarusan.

Sebelum melaksanakan pengambilan data melalui instrumen penelitian berupa tes dan mendapatkan tes yang aik, maka data tes tersebut diuji dan dianalisis. Uji coba dilakukan pada siswa di luar sasaran penelitian, yaitu pada tahun-tahun sebelumnya. Analisis tes yang dilakukan meliputi:

Validitas butir soal dimaksudkan untuk mengetahui kelayakan tes sehingga dapat digunakan sebagai instrument dalam penelitian ini. Dari perhitungan 25 soal diperoleh 20 soal valid. Taraf kesukaran digunakan untuk mengetahui tingkat kesukaran soal. Hasil analisis menunjukkan dari 20 soal yang diuji terdapat: 5 soal muda. 12 soal sedang, 3 soal sukar

Analisis daya pembeda dilakukan untuk mengetahui kemampuan soal dalam membedakan siswa yang berkemampuan tinggi dengan siswa yang berkemampuan rendah. Dari hasil analisis daya pembeda diperoleh soal yang berkriteria sedang 12 soal, berkriteria mudah 5 soal dan sukar 3 soal. Dengan demikian soal-soal tes yang digunakan telah memenuhi syarat-syarat validitas, reliabilitas, taraf kesukaran, dan daya pembeda.

Pada tahap ini peneliti mempersiapkan perangkat pembelajaran yang terdiri dari Rencana Program Pembelajaran 1, soal tes formatif 1 dan pembelajaran interaktif serta alatalat pengajaran yang mendukung.

Dari daya dapat dijelaskan bahwa dengan menggunakan metode smart sheets pembelajaran interaktif. diperoleh nilai rata-rata prestasi belajar siswa adalah 80 dan ketuntasan belajar mencapai $97,29 \%$ atau ada 14 siswa dari 16 siswa sudah tuntas belajar. Hasil tersebut menunjukkan bahwa pada siklus pertama secara klasikal siswa tuntas belajar, karena siswa yang memperoleh nilai $\geq 70$ sebesar $97,29 \%$ lebih besar dari persentase ketuntasan yang dikehendaki yaitu sebesar 95\%.

Hal ini disebabkan karena siswa mengerti apa yang dimaksudkan dan digunakan dalam pembelajaran kelompok dengan menggunakan metode smart sheets pembelajaran interaktif.

Berdasarkan hasil analisis data pada hasil belajar siswa di atas maka peneliti memutuskan untuk tidak melakukan perencanaan tindakan pada siklus selanjutnya untuk menuntaskan pembelajaran lebih lanjut sehingga dapat di lanjutkan pada pembelajaran dan materi berikutnya.

Ketuntasan hasil belajar siswa melalui hasil penelitian ini menunjukkan bahwa dengan menggunakan pembelajaran interaktif memiliki dampak positif dalam meningkatkan prestasi belajar siswa.

Hal ini dapat dilihat dari semakin mantapnya pemahaman siswa terhadap materi yang di diskusikan melalui metode gambar pembelajaran interaktif. (ketuntasan belajar telah tercapai) yaitu $97.29 \%$ ketuntasan belajar siswa secara klasikal telah tercapai.

Melalui hasil peneilitian ini menunjukkan bahwa pengajaran interaktif memiliki dampak positif dalam meningkatkan prestasi belajar siswa.

Hal ini dapat dilihat dari semakin mantapnya pemahaman dan penguasaan siswa terhadap materi yang telah disampaikan guru selama ini (ketuntasan belajar meningkat dari sklus I, II, dan III) yaitu masing-masing 62,50\%, $75,00 \%$, dan $87,50 \%$. Pada siklus III ketuntasan belajar siswa secara klasikal telah tercapai.

Berdasarkan analisis data, diperoleh aktivitas siswa dalam proses pengajaran interaktif menggunakan metode gambar dalam setiap siklus mengalami peningkatan. Hal ini berdampak positif terhadap proses mengingat kembali materi pelajaran yang telah diterima selama ini, yaitu dapat ditunjukkan dengan meningkatnya nilai rata-rata siswa pada setiap siklus yang terus mengalami peningkatan.

Berdasarkan analisis data, diperoleh aktivitas siswa dalam proses pembelajaran dengan pengajaran interaktif yang paling dominan adalah bekerja dengan vano menggunakan alat/media, mendeng: 160 memperhatikan penjelasan guru, dan $\mathrm{d}$ antar siswa/antara siswa dengan guru. Jadi aapat dikatakan bahwa aktivitas isiswa dapat dikategorikan aktif. 
Sedangkan untuk aktivitas guru selama pembelajaran telah melaksanakan langkahlangkah pengajaran berbasis inkuiri dengan baik. Hal ini terlihat dari aktivitas guru yang muncul di antaranya aktivitas membimbing dan mengamati siswa dalam mengerjakan kegiatan, menjelaskan/melatih menggunakan alat, memberi umpan balik/evaluasi/tanya jawab dimana presentase untuk aktivitas di atas cukup besar.

Dari hasil observasi pada siklus kedua, proses belajar mengajar sudah agak lebih baik dan terarah.Beberapa siswa terlihat mulai aktif dalam kelompoknya masing-masing.

Baik itu perhatian, antusias, aktif dalam diskusi, aktif dalam mengajukan pendapat/ide serta menghargai pendapat orang lain. Walaupun ada diantara mereka yang terlihat masih malumalu dalam menyampaikan.

Adapun kondisi siswa pada saat proses belajar-mengajar dengan menggunakan pembelajaran ini adalah :

Kondisi kelas pada saat guru menyampaikan tujuan dan motivasi siswa. Pada siklus kedua ini saat guru menyampaikan tujuan dan motivasi siswa, keadaan kelas terkendali dan beberapa siswa terlihat antusias. Beberapa siswa-siswi terlihat serius dan semangat memperhatikan guru di depan kelas.

Keberhasilan guru memotivasi siswa dapat dilihat saat guru memberikan pertanyaan, beberapa siswa-siswi terlihat aktif dalam menjawab pertanyaan yang diberikan guru.

Pada saat guru memberikan informasi, para siswa mendengarkan secara serius dan kelas dapat dikendalikan dengan baik oleh guru, guru menyampaikan materi pelajaran secara singkat, jelas dan terarah. Guru memberikan kesempatan kepada siswa untuk saling berbagi informasi dan cara dalam menyelesaikan soal-soal latihan yang diberikan kepada teman sekelompoknya.

Terlihat dengan jelas keantusiasan siswa pada saat guru memberikan pertanyaan, siswa dengan cepat merespon dan saling berlomba untuk menjawab pertanyaan yang diberikan. Pada fase ini tidak terdapat kendala yang berarti karena sebagian besar siswa sudah mulai memahami pelaksanaan pembelajaran.
Pada siklus kedua ini pengorganisasian berjalan lancar dan terkendali, siswa dengan tertib bergabung ke dalam kelompok masingmasing sesuai dengan nomor yang telah ditentukan oleh guru, hal ini disebabkan siswa sudah faham dan sudah mulai terbiasa dengan model pembelajaran.

Pada fase ini, siswa-siswi terlihat serius dan aktif dalam mengerjakan lembar kerja siswa pada kelompok masing-masing, siswa terlihat saling bekerjasama antar sesama kelompok dalam memecahkan soal, di sini setiap siswa diberikan kesempatan sebesar-besarnya untuk memberikan ide dan pendapat, juga terlibat dalam diskusi.

Sesekali Guru memberikan bimbingan kepada para siswa agar tidak keluar dari permasalahan atau soal yang diberikan.

Pada saat guru akan mengevaluasi terjadi sedikit keributan kecil karena ada dua siswa yang terlibat percecokan mulut namun suasana kelas dapat ditenangkan oleh guru, setelah suasana kelas kembali kondusif barulah guru menanyakan hasil kerja masing-masing kelompok dengan cara menyebut satu nomor dari sebuah kelompok dan siswa dengan nomor tersebut mengangkat tangan dan mempresentasikan jawaban dari salah satu pertanyaan yang diberikan dan ditanggapi oleh kelompok lain, guru bertindak sebagai moderator sekaligus narasumber.

Pada saat penghargaan diberikan kepada siswa, seluruh kelas menjadi lebih bersemangat dan ramai, dikarenakan tepuk tangan dan teriakan para siswa yang begitu antusias, sehingga member semangat dan motivasi siswa untuk dapat lebih saling bekerjasama dengan anggota kelompoknya, masing-masing demi keberhasilan bersama.

Siklus III, Dari hasil observasi pada siklus ketiga, proses belajar mengajar sudah semakin lebih baik dan terarah. Siswa mulai aktif dalam kelompoknya masing-masing.

Baik itu perhatian, antusias, aktif dalam diskusi, aktif dalam mengajukan pendapat/ide serta menghargai pendapat orang lain.

Adapun kondisi siswa pada saat proses be' mengajar dengan menggunakan pembelajarc 161 adalah sebagai berikut. 
Kondisi kelas pada saat guru menyampaikan tujuan dan motivasi siswa. Pada siklus ketiga ini saat guru menyampaikan tujuan dan motivasi siswa, keadaan kelas terkendali dan siswa antusias. Siswa-siswi terlihat serius dan semangat memperhatikan guru di depan kelas.

Keberhasilan guru memotivasi siswa dapat dilihat saat guru memberikan pertanyaan, siswasiswi terlihat aktif dalam menjawab pertanyaan yang diberikan guru.

Pada saat guru memberikan informasi, para siswa mendengarkan secara serius dan kelas dapat dikendalikan dengan baik oleh guru, guru menyampaikan materi pelajaran secara singkat, jelas dan terarah.

Guru memberikan kesempatan kepada siswa untuk saling berbagi informasi dan cara dalam menyelesaikan soal-soal latihan yang diberikan kepada teman sekelompoknya.

Terlihat dengan jelas keantusiasan siswa pada saat guru memberikan pertanyaan,siswa dengan cepat merespon dan saling berlomba untuk menjawab pertanyaan yang diberikan.

Pada waktu guru mengorganisasikan siswa kepada kelompok belajar pada siklus ketiga ini pengorganisasian berjalan lancer dan terkendali, siswa dengan tertib masuk ke dalam kelompok masing-masing sesuai dengan nomor yang telah ditentukan oleh guru, karena siswa sudah mulai terbiasa dengan model pembelajaran.

Pada saat siswa bekerja dalam kelompok, siswa-siswi terlihat serius dan aktif dalam mengerjakan lembar kerja siswa pada kelompok masing-masing, siswa terlihat saling bekerjasama

\section{PENUTUP}

Berdasarkan hasil kegiatan pembelajaran yang telah dilakukan selama penelitian, dan berdasarkan seluruh pembahasan serta analisis yang telah dilakukan dapat disimpulkan sebagai berikut: 1) Pembelajaran dengan metode smart sheets dalam pelajaran sejarah kebudayaan islam positif dalam meningkatkan prestasi belajar siswa yang ditandai dengan ketuntasan belajar siswa dalam pembelajaran yaitu (97,29\%) 2) Penerapan metode media perpustakaan sekolah pada pembelajaran sejarah kebudayaan islam mempunyai pengaruh positif, yaitu dapat antar sesame kelompok dalam memecahkan soal, siswa boleh memberikan jawaban dari berbagai literatur yang dibawa, dan di sini setiap siswa diberikan kestujuhan sebesar-besarnya untuk memberikan ide dan pendapat, juga terlibat dalam diskusi.

Walaupun begitu guru tetap selalu membimbing para siswa agar tidak keluar dari permasalahan atau soal yang diberikan. Diskusi kelompok berjalan dengan lebih baik dari siklus sebelumnya, hal ini disebabkan setiap siswa merasa bertanggung jawab atas keberhasilan kelompoknya masing-masing.

Sebelum evaluasin berlangsung guru harus mengkondisikan kelas terlebih dahulu, di sini kondisi kelas cukup kondusif, kemudian guru menanyakan hasil kerja masing-masing kelompok dengan cara menyebut satu nomor dari sebuah kelompok dan siswa dengan nomor tersebut mengangkat tangan dan mempresentasikan jawaban dari salah satu pertanyaan yang diberikan dan ditanggapi oleh kelompok lain, guru bertindak sebagai moderator sekaligus narasumber.

Pada siklus ketiga ini hampir sama dengan siklus kedua, dimana pada saat penghargaan diberikan kepada siswa, seluruh kelas menjadi lebih bersemangat dan ramai, dikarenakan tepuk tangan dan teriakan para siswa yang begitu antusias, sehingga member semangat dan motivasi siswa untuk dapat lebih saling bekerjasama dengan anggota kelompoknya masing-masing demi keberhasilan bersama.

meningkatkan motivasi belajar siswa yang ditunjukan dengan rata-rata 80 dan dari hasil wawancara yang menyatakan bahwa siswa tertarik dan berminat dengan metode kooperatif pembelajaran sejarah kebudayaan islam sehingga mereka menjadi termotivasi untuk belajar.

Dari hasil penelitian yang diperoleh dari uraian sebelumnya agar proses belajar mengajar sejarah kebudayaan islam lebih efektif dan memberikan hasil yang optimal bagi siswa, disampaikan saran sebagai berikut: 1) I melaksanakan belajar dengan metode media 
smart sheets pada pembelajaran sejarah kebudayaan islam interaktif memerlukan persiapan yang cukup matang, sehingga guru harus mempu menentukan atau memilih topik yang benar-benar bisa diterapkan dengan metode ini memakai metode kooperatif pembelajaran interaktif dalam proses belajar mengajar sehingga diperoleh hasil yang optimal. 2) Dalam rangka meningkatkan prestasi belajar siswa, guru hendaknya lebih sering melatih siswa dengan berbagainya metode, walau dalam taraf yang sederhana, dimana siswa nantinya dapat menemukan pengetahuan baru, memperoleh konsep dan keterampilan, sehingga siswa berhasil atau mampu memecahkan masalahmasalah yang dihadapinya. Perlu adanya penelitian yang lebih lanjut, karena hasil penelitian ini hanya dilakukan di kelas XI MTsN Tarusan pada bulan Juli 2016. Untuk penelitian yang serupa hendaknya dilakukan perbaikanperbaikan agar diperoleh hasil yang lebih baik.

\section{DAFTAR PUSTAKA}

Arsyad. 2011. Media Pembelajaran. Jakarta : Raja Grafindo Persada.

Briggs. 1982. Evaluationg the Quality of Learning : the SOLO Taxonomy. New York: Academic Press.

Brown. 1973. A First Language : The Early stage. Cambridge, MA : Harvard University Press.

Dimyati. 2002. Belajar dan Pembelajaran. Jakarta : PT Rineka Cipta.

Oemar Hamalik. 1994. Psikologi Belajar dan Mengajar. Bandung : Sinar Baru.
Schramm. 1977. Azas-azas Komunikasi Antar Manusia. Jakarta : LP3ES.

Slameto. 2003. Proses Belajar Mengajar Dalam Sistem Kredit Semester (SKS). Jakarta : Bumi Aksara.

Sobry. 2009. Belajar dan Pembelajaran. Bandung : Prospect.

Soetomo. 1993. Dasar-dasar Interaksi Belajar Mengajar. Surabaya : Usaha Nasional.

Sudjana, N. 1999. Cara Belajar Siswa Aktif dalam Proses Belajar Mengajar. Bandung : Sinar Baru. 